\title{
Bentuk Hubungan Hukum Para Pihak dan Tanggung Jawab Agen dalam Penyelenggaraan Branchless Banking di Indonesia
}

\author{
Inda Rahadiyan dan M. Alif Akbar Pranagara \\ Fakultas Hukum Universitas Islam Indonesia \\ Jln. Tamansiswa No. 158 Yoyakarta \\ indarahadiyan1@gmail.com, alifpranagara@gmail.com
}

\begin{abstract}
The problems analyzed in this research include: first, how is the legal relation among parties in the implementation of Branchless Banking in Indonesia? Second, how is the liability of agents in the implementation of Branchless Banking in Indonesia? The research was conducted by using normative juridical method supported with empirical data. The results showed that, first, the form of the legal relation between agents of Branchless Banking with banks is different from that between the agents and principals on the basis of agency agreement. Second, the legal liability imposed on Branchless Banking agents may not be equalized with the agents' liabilities arising under a general agency agreement.
\end{abstract}

Key words: Legal relations; agent; Branchless Banking; Indonesia

\section{Abstrak}

Permasalahan yang dikaji dalam penelitian ini meliputi: pertama, bagaimana bentuk hubungan hukum para pihak dalam penyelenggaraan Branchless Banking di Indonesia? Kedua, bagaimana tanggung jawab agen dalam penyelenggaraan Branchless Banking di Indonesia? Penelitian dilakukan dengan menggunakan metode yuridis normatif didukung data empiris. Hasil penelitian menunjukkan bahwa pertama, bentuk hubungan hukum antara agen Branchless Banking dengan bank berbeda dengan bentuk hubungan hukum antara agen dengan prinsipal berdasarkan suatu perjanjian keagenan. Kedua, tanggung jawab hukum yang dibebankan kepada agen Branchless Banking juga tidak dapat dipersamakan dengan tanggung jawab agen yang muncul berdasarkan suatu perjanjian keagenan pada umumnya.

Kata-kata Kunci: Hubungan hukum; agen; Branchless Banking; Indonesia 


\section{Pendahuluan}

Indeks keuangan inklusif ${ }^{1}$ Indonesia merupakan salah satu yang terendah di kawasan Asia Tenggara. ${ }^{2}$ Fakta ini menunjukkan beberapa hal berkaitan dengan penyelenggaraan layanan keuangan formal termasuk sektor perbankan. Rendahnya indeks keuangan inklusif menunjukkan bahwa penyelenggaraan layanan perbankan masih belum mampu menyentuh seluruh lapisan masyarakat yang kemudian berakibat pada rendahnya rasio angka kredit terhadap jumlah Pendapatan Domestik Bruto (PDB) ${ }^{3}$ Indonesia. ${ }^{4}$ Data ini setidaknya memberikan sebuah argumentasi mendasar bahwa permasalahan mengenai masih rendahnya akses masyarakat terhadap layanan perbankan merupakan suatu permasalahan serius yang memerlukan upaya-upaya penanganan baik oleh pihak otoritas perbankan ${ }^{5}$ maupun oleh kalangan penyelenggara usaha perbankan.

Keterbatasan akses terhadap layanan perbankan yang dihadapi oleh sebagian masyarakat di wilayah-wilayah tertentu pada tataran selanjutnya mengakibatkan bank tidak dapat melaksanakan fungsinya secara optimal sebagai lembaga intermediasi keuangan ${ }^{6}$ yang memiliki tujuan untuk meningkatkan taraf hidup

1 Indeks keuangan inklusif adalah salah satu cara alternatif untuk mengukur kondisi keuangan inklusif dengan menggunakan indeks multidimensional berdasarkan data makroekonomi, terutama pada jangkauan layanan sektor perbankan, lihat: http://www.bi.go.id Sementara itu, Inklusi keuangan (financial inclusion) tidak memiliki definisi baku yang berlaku secara universal. Salah satu rumusan definisi keuangan inklusif yakni: financial inclusion or inclusive financing is the delivery of financial services at affordable cost to sections of disadvantages and low income segments of society, in contrast to financial exclusion where those services are not available or affordable. An estimated 2,5 billion working age adults globally have no access to the types of formal financial services delivered by regulated financial institutions. It is argued that as banking services are in nature of public good; the availability of banking and payment services to the entire population without discrimination is the prime objective of financial inclusion public policy. Uraian lebih lanjut baca: Alifa Prasasti Rahmaningrum, "Tinjauan Yuridis Atas Risiko Penyelenggaraan Branchless Banking Dalam Kaitannya Dengan Kesehatan Bank, 2013, Tesis, Magister Ilmu Hukum Fakultas Hukum Universitas Gadjah Mada, hlm.7.

${ }^{2}$ Data sebagaimana dikutip dari website resmi Bank Indonesia, Inklusi Keuangan, www.bi.go.id diakses pada tanggal 20 November 2016.

3 Pendapatan Domestik Bruto (PDB) pada dasarnya merupakan jumlah nilai tambah yang dihasilkan oleh seluruh unit usaha dalam suatu negara tertentu, atau merupakan jumlah nilai barang dan jasa akhir yang dihasilkan oleh seluruh unit ekonomi. Lihat: "Pengertian Pendapatan Nasional", http://www.bps.go.id diakses pada tanggal 18 Januari 2017.

${ }^{4}$ Rasio angka kredit dengan PDB hanya mencapai 32, 85\%. Lihat: Timothy R. Lyman, Gautam Ivatury, and Stefan Staschen, "Use of Agents in Branchless Banking for the Poor: Rewards, Risk and Regulation", The Consultative Group to Assist the Poor, Focus Note Number 38, October 2008, http://www.cgap.org

${ }_{5}^{5}$ Otoritas perbankan dalam hal ini adalah Otoritas Jasa Keuangan (OJK) sebagaimana diatur di dalam Undang-Undang Nomor 21 Tahun 2011 tentang Otoritas Jasa Keuangan.

${ }^{6}$ Keberadaan bank beserta kegiatan usahanya merupakan elemen pokok di dalam sistem perbankan. Sebagai bagian utama dari sistem perbankan, kelembagaan bank menjalankan fungsi sebagai lembaga intermediasi keuangan (financial intermediary institution). Lihat: Rachmadi Usman, Aspek-Aspek. Hukum Perbankan di Indonesia, 2001, Jakarta, PT. Gramedia Pustaka Utama, hlm.24. Dalam kedudukannya sebagai lembaga intermediasi keuangan, bank melaksanakan dua kegiatan utama berupa penghimpunan dan penyaluran dana. Dana dihimpun dari pihak yang memiliki kelebihan (surplus unit) dan disalurkan kepada pihak yang kekurangan (defisit unit). Lihat: Carnell, Macey, Miller, 2009, The Law of Banking and Financial Institution: Fourth Edition, New York, Aspen Publisher. 
rakyat banyak. ${ }^{7}$ Dengan demikian, diperlukan inovasi dalam penyelenggaraan layanan perbankan agar bank dapat melaksanakan fungsinya secara optimal. ${ }^{8}$ Berbagai upaya dalam rangka optimalisasi peran sektor perbankan ini juga dilatarbelakangi oleh kajian-kajian ilmiah yang menunjukkan urgensi sektor perbankan bagi pertumbuhan ekonomi. ${ }^{9}$

Salah satu inovasi layanan perbankan termanifestasi ke dalam penyelenggaraan Branchless Banking. Secara sederhana Branchless Banking dapat didefinisikan sebagai suatu mekanisme penyelenggaraan layanan perbankan tanpa menghadirkan keberadaan kantor cabang bank secara fisik. ${ }^{10}$ Dalam Bahasa Indonesia, mekanisme ini dikenal pula dengan istilah bank tanpa kantor cabang. ${ }^{11}$

Secara umum penyelenggaraan Branchless Banking dilakukan dengan melibatkan peran serta agen selaku perantara yang melaksanakan pelayanan jasa perbankan dan berhubungan langsung dengan para pengguna layanan baik nasabah maupun non nasabah bank. Branchless Banking diyakini sebagai suatu inovasi yang mampu mengoptimalkan fungsi bank mengingat penggunaan agen dalam penyelenggaraan layanan ini memiliki potensi besar untuk memperluas penyaluran jasa keuangan kepada kelompok masyarakat menengah ke bawah. Kelompok masyarakat menengah ke bawah dalam hal ini khususnya kelompok masyarakat yang baru pertama kali memperoleh akses layanan perbankan. ${ }^{12}$

Sebelum diterapkan di Indonesia, mekanisme Branchless Banking telah diterapkan di beberapa negara berkembang. Setidaknya tercatat beberapa negara

${ }^{7}$ Pasal 1 Angka 1 Undang-Undang Nomor 7 Tahun 1992 tentang Perbankan

${ }^{8}$ Jenis-jenis cara baru yang telah dikembangkan untuk menyelenggarakan layanan perbankan antara lain dilakukan melalui media Automatic Teller Machine atau Anjungan Tunai Mandiri (ATM) yang memudahkan nasabah bank dalam menarik uang tanpa harus mendatangi kantor bank. Lihat: "Solusi Kemudahan Transaksi", http://www.bca.co.id.sp. Dalam perkembangan selanjutnya, melalui ATM masyarakat memperoleh kemudahan untuk melakukan transaksi penyetoran, pengiriman dan pembayaran. Setelah kemunculan ATM, muncul pula berbagai jenis pelayanan nasabah berbasis teknologi informasi seperti Mobile Banking (Phone atau SMS Banking) dan Internet Banking. Lihat: "Profil M.Banking BCA', http://www.bca.co.id/mbca

${ }^{9}$ Uraian secara lebih mendalam mengenai kajian ini baca: "Barth, Caprio, Jr. and Levine, Banking System around the Globe: Do Regulation and Ownership Affect Performance and Stability?" http://www.business.auburn.edu diakses pada tanggal 20 Desember 2015.

${ }^{10}$ Claire Alexandre, "What Can Branchless Banking Do to Advance the Field, and What Can It Not Do? From Mobile Banking to Point of Service” artikel pada 2011 Global Microcredit Summit, 2011, hlm. 4

11 Secara umum, Branchless Banking deidefinisikan sebagai: Branchless Banking represents a new distribution channel that allows financial institutions and other commercial actors to offer financial services outside traditional bank premises. Some models of Branchless Banking — for example, internet banking and automatic teller machines (ATMs) can be seen as modest extensions of conventional branch—based banking. Lihat: Timothy..., Loc. Cit.

${ }^{12}$ Ibid. 
seperti Kenya, Brazil, Pakistan serta Filipina ${ }^{13}$ yang telah terlebih dahulu sukses menerapkan Branchless Banking. ${ }^{14}$

Penerapan Branchless Banking di Indonesia dilaksanakan baik oleh Bank Indonesia maupun Otoritas Jasa Keuangan. Bank Indonesia menerapkan Branchless Banking melalui program Layanan Keuangan Digital (LKD). Sementara itu, Otoritas Jasa Keuangan menerapkan Branchless Banking melalui program Layanan Keuangan Tanpa Kantor dalam Rangka Keuangan Inklusif (Laku Pandai). ${ }^{15}$ Program Laku Pandai bertujuan untuk mewujudkan keuangan inklusif ${ }^{16}$, yakni suatu sistem keuangan formal yang dapat diakses dengan mudah oleh seluruh lapisan masyarakat. ${ }^{17}$

Branchless Banking18 berkaitan dengan beberapa aspek hukum keperdataan yang menarik untuk dikaji terutama mengenai bentuk hubungan hukum di antara para pihak. Hal ini dapat dipahami mengingat hubungan hukum di antara para pihak akan berkaitan pula dengan beberapa aspek hukum lainnya seperti hak dan kewajiban serta tanggung jawab para pihak.

Apabila dikaji berdasarkan regulasi yang menjadi dasar penyelenggaraan Branchless Banking di Indonesia, ${ }^{19}$ dapat dikatakan bahwa regulasi yang ada saat ini lebih cenderung memberikan pengaturan dari segi administratif, sementara perihal bentuk hubungan hukum para pihak dan kedudukan agen belum diatur secara jelas. Kondisi demikian tentu akan berpotensi menyebabkan munculnya persoalan hukum.

Salah satu diantara persoalan hukum yang berpotensi muncul di dalam praktek adalah mengenai tanggung jawab agen dalam penyelenggaraan Branchless Banking. Tanggung jawab agen menjadi sangat penting mengingat agen adalah

\footnotetext{
13 Shri L.S. Subramanian, "a Study of Branchless Banking in Achieving Financial Inclusion in India”. BVTMSR's Journal of Management Research. Vol. 5 Issue -2: October 2013.

${ }^{14}$ Siaran Pers Otoritas Jasa Keuangan, "OJK Resmikan Program Laku Pandai”, http://www.ojk.go.id, diakses pada tanggal 01 Februari 2016.

${ }^{15}$ Ibid.

${ }^{16}$ Lihat: Alifa Prasasti Rahmaningrum, Loc. Cit.

${ }_{17}$ Bank Indonesia telah menjadikan perwujudan sistem keuangan inklusif sebagai salah satu agenda besar guna mendorong pertumbuhan ekonomi, pemerataan pendapatan, pengentasan kemiskinan, serta perwujudan stabilitas sistem keuangan. Hal ini sejalan pula dengan rilis Bank Dunia yang memposisikan program keuangan inklusif sebagai kunci bagi pengentasan kemiskinan dan pemerataan kesejahteraan. Lihat: "Financial Inclusion", http://www.worldbank.org

${ }^{18}$ Ibid.

${ }^{19}$ Baca Peraturan Otoritas Jasa Keuangan Nomor 19 .03/POJK Tahun 2014 tentang Layanan Keuangan Tanpa Kantor Dalam Rangka Keuangan Inklusif.
} 
pihak yang memberikan berbagai layanan jasa perbankan secara langsung kepada masyarakat.

\section{Rumusan Masalah}

Permasalahan yang dikaji dalam penelitian ini meliputi; pertama, bagaimanakah bentuk hubungan hukum para pihak dalam penyelenggaraan Branchless Banking di Indonesia? Kedua, bagaimanakah tanggung jawab agen dalam penyelenggaraan Branchless Banking di Indonesia?

\section{Tujuan Penelitian}

Penelitian ini bertujuan untuk: pertama, mengetahui dan menganalisis bentuk hubungan hukum para pihak dalam penyelenggaraan Branchless Banking di Indonesia. Kedua, mengetahui dan menganalisis tanggung jawab agen dalam penyelenggaraan Branchless Banking di Indonesia?

\section{Metode Penelitian}

Metode yang digunakan dalam rangka menjawab rumusan masalah dalam penelitian ini adalah metode penelitian hukum normatif dengan didukung data empiris. Penelitian hukum normatif dilakukan melalui studi kepustakaan dengan mengumpulkan, mempelajari serta menganalisis data hasil penelitian yang relevan guna menjawab permasalahan penelitian. Data hasil penelitian kemudian disajikan secara kualitatif sesuai relevansinya dengan rumusan masalah. ${ }^{20}$

\section{Hasil Penelitian dan Pembahasan}

Branchless Banking Sebagai Salah Satu Program Perwujudan Keuangan Inklusif

Pembicaraan mengenai Branchless Banking tidak dapat dipisahkan dari pembicaraan mengenai keuangan inklusif (financial inclusion). Hal ini dapat dipahami mengingat secara universal, Branchless Banking merupakan bagian dari strategi perwujudan keuangan inklusif.

World Bank mendefinisikan keuangan inklusif sebagai: "financial inclusion means that individuals and businesses have access to useful and affordable financial

${ }^{20}$ Lihat: Johny Ibrahim, Teori dan Metodologi Penelitian Normatif, Banyumedia Publishing, Malang, 2006, hlm. 63. 
products and services that meet their needs-transactions, payments, savings, credit and insurance-delivered in a responsible and sustainable way."21 Berdasarkan rumusan definisi dimaksud sekiranya dapat ditarik sebuah kesimpulan bahwa inti dari inklusi keuangan adalah tersedianya layanan keuangan (formal) yang dapat diakses atau dijangkau dengan mudah oleh setiap anggota masyarakat.

Hasil survei Bank Dunia pada 2010 menunjukkan bahwa kepemilikan rekening bank oleh warga dewasa di Indonesia baru mencapai angka 19,6 persen. Indeks financial inclusion Indonesia bahkan tercatat sebagai salah satu yang terendah di kawasan ASEAN.22 Walaupun indeks financial inclusion Indonesia meningkat pada angka 36 persen pada 201623, akses masyarakat terhadap layanan jasa keuangan resmi (termasuk perbankan) masih tergolong rendah. ${ }^{24}$

Kondisi demikian kemudian mendorong pemerintah untuk menetapkan kebijakan baru dalam rangka optimalisasi akses masyarakat terhadap layanan jasa keuangan. Kebijakan ini dikenal dengan Strategi Nasional Keuangan Inklusi (SNKI) yang pertama kali dicanangkan oleh Bank Indonesia. Branchless Banking merupakan salah satu program yang menjadi bagian pokok dalam penyelenggaraan SNKI. ${ }^{25}$

Kedua otoritas perbankan yakni Bank Indonesia dan Otoritas Jasa Keuangan kemudian mengeluarkan program lanjutan sebagai implementasi SNKI melalui mekanisme Branchless Banking. Bank Indonesia mengeluarkan program Layanan Keuangan Digital (LKD) ${ }^{26}$ dan Otoritas Jasa Keuangan mengeluarkan program Layanan Keuangan Tanpa Kantor dalam rangka Keuangan Inklusif (Laku Pandai). Baik LKD maupun Laku Pandai keduanya merupakan bentuk implementasi Branchless Banking sebagai sarana perwujudan inklusi keuangan di Indonesia.

Bentuk implementasi Branchless Banking di Indonesia, OJK telah pula merumuskan definisi terhadap istilah keuangan inklusif. Berdasarkan Peraturan

${ }^{21}$ Financial Inclusion, the World Bank Overview, www.worldbank.org diakses pada tanggal 19 Januari 2017.

${ }^{22}$ World Bank, Financial Access, the Consultative Group to Assist the Poor, 2010, hlm. 23.

${ }^{23}$ Baca: Ina Parlina, Indonesia Promotes Financial Inclusion with New Strategy, http://thejakartapost.com diakses pada tanggal 20 April 2017.

${ }^{24}$ Data lebih rinci mengenai indeks financial inclusion lihat: Financial Inclusion, http://www.worldbank.org

25 Bank Indonesia, Departemen Penelitian dan Pengaturan Perbankan, Strategi Nasional Keuangan Inklusif, www.bi.go.id

26 Program LKD sebagaimana diatur dalam Peraturan Bank Indonesia Nomor 11/12/PBI/2009 tentang Uang Elektronik jo. Peraturan Bank Indonesia Nomor 18/17/PBI/2016 tentang Perubahan Kedua atas PBI Nomor 11/12/PBI/2009 tentang Uang Elektronik. 
OJK tentang Laku Pandai yang dimaksud dengan keuangan inklusif adalah suatu keadaan dimana seluruh masyarakat dapat menjangkau akses layanan keuangan secara mudah dan memiliki budaya untuk mengoptimalkan penggunaan jasa keuangan. ${ }^{27}$

\section{Hubungan Hukum Para Pihak dalam Penyelenggaraan Branchless Banking di Indonesia}

Penyelenggaraan Branchless Banking 28 melibatkan peran tiga subjek hukum yakni bank, nasabah atau masyarakat non nasabah serta agen. Mengingat penyedia layanan dalam Branchless Banking sejatinya tetaplah pihak bank, maka hak dan kewajiban yang muncul antara bank dengan pengguna layanan dalam penyelenggaraan Branchless Banking tetap berlandaskan pada hubungan hukum antara bank dengan pengguna layanan ${ }^{29}$ sebagaimana penyelenggaraan layanan perbankan pada umumnya. ${ }^{30}$ Ada pun konstruksi hubungan hukum yang dikaji dalam penelitian ini difokuskan pada konstruksi hubungan hukum antara bank dengan agen berdasarkan peraturan mengenai Laku Pandai dan implementasinya di dalam praktek. ${ }^{31}$

Peraturan OJK tentang Laku Pandai mendefinisikan Laku Pandai sebagai kegiatan menyediakan layanan perbankan dan/ atau layanan keuangan lainnya yang dilakukan tidak melalui jaringan kantor, tetapi melalui kerjasama dengan pihak lain dan perlu didukung dengan penggunaan sarana teknologi informasi. ${ }^{32}$ Yang dimaksud dengan pihak lain dalam rumusan pasal tersebut adalah agen selaku perantara dalam mekanisme Laku Pandai sebagai bentuk adopsi Branchless Banking di Indonesia.

\footnotetext{
${ }^{27}$ Pasal 1 angka 5 POJK No. 19/POJK.03/2014 tentang Layanan Keuangan Tanpa Kantor Dalam Rangka Keuangan Inklusif.

${ }^{28}$ Penyelenggaraan Branchless Banking yang menjadi focus kajian dalam penelitian ini adalah penyelenggaran Laku Pandai sebagaimana diatur dalam POJK No. 19/POJK.03/2014 tentang Layanan Keuangan Tanpa Kantor Dalam Rangka Keuangan Inklusif

${ }^{29}$ Pengguna layanan dalam hal ini meliputi baik pengguna layanan yang merupakan nasabah bank maupun pengguna layanan yang bukan merupakan nasabah bank.

30 Yang dimaksud dengan 'penyelenggaraan layanan perbankan pada umumnya' dalam hal ini adalah penyelenggaraan layanan perbankan melalui keberadaan kantor bank secara fisik.

31 Penyelenggaraan Layanan Keuangan Digital oleh Bank Indonesia yang juga nerupakan bentuk penerapan Branchless Banking sebagaimana diatur di dalam PBI Nomor 18/17/PBI/2016 tentang Perubahan Kedua atas PBI Nomor 11/12/PBI/2009 tentang Uang Elektronik tidak termasuk dalam fokus kajian penelitian ini.

32 Pasal 1 angka 3 POJK No. 19/POJK.03/2014 Tentang Layanan Keuangan Tanpa Kantor Dalam Rangka Keuangan Inklusif.
} 
Istilah hubungan hukum dikenal pula dengan istilah rechtsverhouding atau rechtsbetrekking. Hubungan hukum adalah hubungan yang terjadi antara subjek hukum yang satu dengan subjek hukum lainnya dalam masyarakat sebagaimana diatur oleh hukum. Hubungan hukum tercermin pada melekatnya hak dan kewajiban masing-masing pihak yang terikat dalam suatu perjanjian. ${ }^{33}$ Dengan perkataan lain, hubungan hukum adalah suatu hubungan antara subjek hukum yang satu dengan subjek hukum lain yang menimbulkan konsekuensi hukum berupa hak dan kewajiban. Pertanyaan mendasar yang perlu dijawab berkaitan dengan konstruksi hubungan hukum ini adalah apakah bentuk hubungan hukum yang lahir berdasarkan perjanjian keagenan sebagaimana dikenal dalam teori keperantaraan bisnis sama dengan keagenan yang berlaku dalam penyelenggaraan Branchless Banking?

Keagenan merupakan sebuah konsep keperantaraan bisnis yang pengaturannya berada di luar KUH Perdata dan KUH Dagang. ${ }^{34}$ Eksistensi Agen selaku perantara perdagangan diatur dalam Peraturan Menteri Perdagangan RI No. 11/M-DAG/PER/3/2006 tentang Ketentuan dan Tata Cara Penerbitan Surat Tanda Pendaftaran Agen atau Distributor Barang dan/ atau Jasa.

Sebagaimana suatu peraturan pelaksana yang bersifat teknis, peraturan menteri mengenai agen perdagangan lebih bersifat administratif dan tidak menyentuh substansi hukum berkaitan dengan pokok keagenan. Hal demikian mengakibatkan konsep-konsep dasar mengenai hubungan hukum yang terjadi diantara prinsipal dengan agen tidak diatur di dalam peraturan menteri dimaksud dan oleh karena itu harus dikembalikan kepada doktrin/teori hukum mengenai keagenan. ${ }^{35}$

Eksistensi hubungan hukum antara prinsipal dengan agen didasarkan pada suatu perjanjian keagenan. Perjanjian keagenan adalah perjanjian antara seorang prinsipal dengan seorang perantara dimana seorang perantara mengikatkan diri kepada prinsipal untuk melakukan perbuatan hukum tertentu bagi kepentingan

33 Sudikno Mertokusumo, Mengenal Hukum Suatu Pengantar, 2005, Penerbit Liberty, Yogyakarta, hlm. 41.

34 Ridwan Khairandy, Pokok-Pokok Hukum Dagang Indonesia, 2013, FH UII Press, Yogyakarta, hlm. 247

35 Dalam bahasa Inggris teori keagenan ini dikenal dengan istilah agency theory. Berbagai pengkajian berkaitan dengan teori ini dapat dilakukan baik dengan menggunakan pendekatan hukum maupun pendekatan ekonomi. Uraian lebih lanjut mengenai pembahasan agency theory berdasarkan perspektif hukum dan ekonomi, antara lain lihat: Paula J. Dalley, “A Theory of Agency Law”, https://lawreview.law.pitt.edu 
prinsipal. Dalam hal ini, prinsipal memberikan pula kewenangan kepada perantara untuk mengadakan perjanjian dengan pihak ke tiga guna kepentingan prinsipal. ${ }^{36}$

Berdasarkan konstruksi pengertian demikian, maka prinsipal adalah pihak yang memberikan wewenang kepada perantara untuk melakukan perbuatan hukum dengan pihak ke tiga demi kepentingan prinsipal. Sementara perantara adalah pihak yang menerima wewenang dari prinsipal untuk mengadakan perjanjian dengan pihak ketiga demi kepentingan prinsipal. ${ }^{37}$

Konsepsi hubungan hukum dapat dikaji berdasarkan perbuatan-perbuatan hukum yang melahirkan hak dan kewajiban bagi para pihak berdasarkan suatu perjanjian. Dalam rangka mengkaji bentuk hubungan hukum yang terjadi antara bank dengan agen dalam mekanisme Laku Pandai, peneliti mengkaji hubungan hukum yang terjadi dalam penyelenggaraan Branchless Banking oleh salah satu bank pemerintah di Indonesia.

Berdasarkan riset yang telah dilakukan oleh peneliti, pada kenyatannya masih terdapat Agen Branchless Banking 38 yang tidak mengetahui adanya perjanjian tertulis dengan pihak bank penyelenggara. ${ }^{39}$ Agen hanya mendapatkan penunjukan langsung dari bank untuk menjadi agen Branchless Banking. Penunjukan agen oleh bank tidak disertai dengan penjelasan secara jelas dan lengkap mengenai hak dan kewajiban para pihak beserta konsekuensi hukumnya. ${ }^{40}$

Fakta mengenai penunjukan agen oleh bank penyelenggara Branchless Banking tersebut dapat menimbulkan permasalahan hukum tersendiri. Permasalahan hukum terutama menyangkut kepastian mengenai hak dan kewajiban para pihak. Hal ini menjadi sangat penting mengingat hak dan

\footnotetext{
${ }^{36}$ Ridwan Khairandy, Pokok-Pokok Hukum Dagang, Op. Cit., hlm. 248. Lihat juga Richard Burton, Aspek Hukum dalam Bisnis, Rineka Cipta, Jakarta, 2003.

${ }^{37}$ Yesi Hendriani Supartoyo, Kasmiati, Branchless Banking Mewujudkan Kenangan Inklusif sebagai Alternatif Solusi Inovatif Menanggulangi Kemiskinan: Review Dan Rekomendasi, hlm. 11.

38 Agen Branchless Banking dalam hal ini adalah beberapa contoh agen Branchless Banking yang memiliki sebutan berbeda-beda di dalam praktek. Di dalam praktek, pemberian dan penyebutan nama agen Branchless Banking ini berbeda antara satu bank dengan bank yang lain. Sebagai contoh, agen Laku Pandai BRI disebut dengan Agen BRI-Link, Agen Laku Pandai BCA disebut dengan istilah Agen LAKU sementara pada bank BTN dikenal pula istilah Griya Bayar BTN.

${ }^{39}$ Hasil wawancara dengan Ibu Lismawati selaku Agen Branchless Banking pada salah satu bank pemerintah di Indonesia yang bertempat kedudukan di Kota Palembang pada tanggal 16 Januari 2016

${ }^{40}$ Hasil wawancara dengan Lismawati selaku salah satu agen Laku Pandai di Kota Palembang pada tanggal 10 Februari 2016.
} 
kewajiban para pihak di dalam suatu perjanjian akan berimplikasi pada tanggung jawab hukum masing-masing pihak terhadap pelaksanaan isi perjanjian.

Implementasi Branchless Banking khususnya berkaitan dengan penunjukan agen dapat dikatakan beragam (berbeda antara satu bank dengan bank lainnya) di dalam praktek. Sebagai contoh, penunjukkan agen dapat dilakukan melalui penunjukan lisan oleh bank kepada nasabah-nasabah tertentu atau dapat pula penunjukkan dilakukan dengan cara yang lebih formal sampai pada penjelasan teknis isi perjanjian antara bank dengan agen. Hal demikian disebabkan karena regulasi yang ada ${ }^{41}$ menyerahkan pengaturan secara lebih lanjut mengenai perjanjian antara bank dengan agen kepada masing-masing bank penyelenggara. ${ }^{42}$

Peraturan OJK mengenai Laku Pandai mendefinisikan agen sebagai pihak yang bekerjasama dengan Bank penyelenggara Laku Pandai yang menjadi kepanjangan tangan Bank untuk menyediakan layanan perbankan kepada masyarakat dalam rangka keuangan inklusif sesuai yang diperjanjikan. ${ }^{43}$ Rumusan definisi demikian setidaknya mengandung dua substansi pengaturan mengenai bentuk hubungan hukum yang terjadi antara bank dengan agen. Pertama, bentuk hubungan hukum yang terjadi antara bank dengan agen dapat dikatakan sebagai suatu bentuk hubungan hukum yang lahir dari perjanjian (kerjasama). Kedua, eksistensi kedudukan agen selaku kepanjangan tangan bank.

Konstruksi hubungan hukum yang lahir dari rumusan definisi agen dalam Peraturan OJK dimaksud berpotensi menimbulkan suatu kekaburan mengenai bentuk hubungan hukum yang sejatinya terjadi antara bank dengan agen. Bank dikatakan melakukan kerjasama dengan agen, akan tetapi rumusan kalimat definisi tersebut menjadi kabur karena ditambahkan dengan kedudukan agen sebagai 'perpanjangan tangan' bank. Penggunaan istilah 'perpanjangan tangan' dapat menimbulkan penafsiran bahwa agen tidak memiliki kedudukan setara dengan bank sebagaimana kesetaraan para pihak dalam suatu perjanjian. ${ }^{44}$

\footnotetext{
${ }^{41}$ Regulasi yang dimaksud dalam hal ini adalah POJK No. 19/POJK.03/2014 tentang Layanan Keuangan Tanpa Kantor Dalam Rangka Keuangan Inklusif.

${ }^{42}$ Hasil wawancara dengan Ibu Surach Winarni selaku pakar hukum perbankan sekaligus Kepala Divisi Operasional Bank Mandiri Wilayah Yogyakarta-Jawa Tengah pada tanggal 16 Januari 2016.

${ }^{43}$ Pasal 1 angka 4 POJK No. 19/POJK.03/2014 tentang Layanan Keuangan Tanpa Kantor Dalam Rangka Keuangan Inklusif.

44 Pengertian perjanjian sebagaimana diatur dalam Pasal 1313 Kitab Undang-Undang Hukum Perdata adalah suatu perbuatan dengan mana satu pihak atau lebih mengikatkan dirinya terhadap satu orang lain atau lebih.
} 
Di dalam praktek, isi kerjasama yang tertuang dalam kontrak antara bank penyelenggara Laku Pandai dengan agen diserahkan sepenuhnya kepada pihak bank. OJK selaku otoritas perbankan memberikan kebebasan ${ }^{45}$ kepada masingmasing bank penyelenggara untuk mengatur dan menentukan isi kontrak. Kondisi demikian berpotensi mengakibatkan implementasi yang beragam terhadap penyebutan nama dan isi kontrak antara bank dengan agen Laku Pandai. ${ }^{46}$ Nama dan isi kontrak yang beragam pada tataran selanjutnya berpotensi menimbulkan kesulitan untuk mengidentifikasi bagaimana sejatinya bentuk hubungan hukum yang terjadi di antara para pihak beserta tanggung jawab yang timbul dari hubungan hukum tersebut.

Di Indonesia, agen Branchless Banking dalam hal ini Laku Pandai memiliki nama dan sebutan umum yang sama dengan agen perdagangan yakni keduanya disebut dengan istilah 'agen'. Namun demikian, secara subtansial agen Laku Pandai memiliki kedudukan yang berbeda dengan agen perdagangan. ${ }^{47}$ Perbedaan tersebut menunjukkan pula adanya perbedaan bentuk hubungan hukum yang terjadi antara agen Laku Pandai dan agen perdagangan dengan pihak prinsipalnya masing-masing.

Dalam perjanjian keagenan, agen diberikan wewenang oleh prinsipal untuk melakukan perbuatan hukum termasuk melakukan perikatan dengan pihak ketiga demi kepentingan prinsipal. Agen bukanlah pihak di dalam perjanjian yang dibuat antara prinsipal dengan pihak ketiga. Konsekuensinya, agen tidak dapat dibebani tanggung jawab hukum atas timbulnya kerugian pihak ketiga sepanjang agen telah melaksanakan kewenangan sebagaimana diberikan oleh prinsipal. ${ }^{48}$

\footnotetext{
Dalam perkembangannya, definisi perjanjian sebagaimana terdapat di dalam Pasal 1313 Kitab Undang-Undang Hukum Perdata tersebut banyak mendapat kritik dari para ahli hukum. Kritik tersebut menyangkut rumusan definisi yang dianggap terlalu luas dan tidak lengkap. Uraian secara lebih lanjut mengenai hal ini antara lain lihat dalam: J. Satrio, Hukum Perjanjian, Bandung, PT. Citra Aditya Bakti, 1992, hlm. 23-24.

${ }^{45}$ Kebebasan untuk menentukan isi kontrak dalam hal ini dibatasi oleh ketentuan mengenai materi muatan pokok isi kontrak yang wajib diatur oleh kedua belah pihak. Dengan kata lain, POJK No. 19/POJK.03/2014 tentang Layanan Keuangan Tanpa Kantor Dalam Rangka Keuangan Inklusif memberikan pedoman mengenai hal-hal yang wajib diatur dalam kontrak penyelenggaraan Branchless Banking. Baca Pasal 22 ayat (2) POJK No. 19/POJK.03/2014 dimaksud.

${ }^{46}$ Hasil wawancara dengan Surach Winarni selaku pakar dan praktisi hukum perbankan pada tanggal 21 April 2016.

47 Agen perdagangan ini sebagaimana diatur dalam Peraturan Menteri Perdagangan RI No.11/MDAG/PER/3/2006.

${ }^{48}$ Ridwan Khairandy, Pokok-Pokok Hukum Dagang Indonesia, Loc. Cit.
} 
Sementara itu, agen Branchless Banking memiliki wewenang yang berbeda dengan kewenangan sebagaimana muncul dari perjanjian keagenan. Walaupun sama-sama disebut sebagai 'Agen', Agen Branchless Banking memiliki wewenang serta hak dan kewajiban yang berbeda dan lebih luas sebagaimana diatur oleh peraturan perundang-undangan dan perjanjian antara setiap Agen dengan masingmasing bank penyelenggara. Mengingat konstruksi yang demikian maka tanggung jawab yang dibebankan kepada seorang Agen Branchless Banking tidak dapat dipersamakan dengan tanggung jawab agen pada umumnya berdasarkan suatu perjanjian keagenan. Hal ini diperkuat dengan fakta bahwa kerja sama antara Agen dengan Bank Penyelenggara Laku Pandai pada dituangkan dalam suatu perjanjian standar yang berbeda antara satu bank dengan bank lainnya. ${ }^{49}$

Berdasarkan pada uraian baik terhadap segi normatif maupun praktik penyelenggaraan Branchless Banking sebagaimana telah diuraikan, maka dapat ditarik sebuah kesimpulan bahwa tanggung jawab Agen Branchless Banking memiliki cakupan yang lebih luas dan tidak dapat dipersamakan dengan tanggung jawab agen sebagaimana bersumber dari perjanjian keagenan. Seorang Agen Branchless Banking secara mendasar bertanggung jawab untuk melaksanakan segala ketentuan hukum sebagaimana dibebankan pada penyelenggaraan kegiatan perbankan oleh bank.

\section{Tanggung Jawab Agen dalam Penyelenggaraan Branchless Banking di Indonesia}

Mengingat penggunaan istilah agen dalam Laku Pandai ditujukan bagi pihak ke tiga yang bekerjasama dengan bank dalam memberikan layanan perbankan kepada masyarakat, ${ }^{50}$ maka persoalan konstruksi kedudukan hukum agen menjadi penting untuk dikaji sebelum menguraikan kajian mengenai tanggung jawab agen. Hal demikian dapat dipahami karena kedudukan hukum agen akan berimplikasi pada tanggung jawab agen.

Agen Branchless Banking memiliki peran penting sebagai perantara dalam berbagai kegiatan perbankan yang terjadi antara bank dengan masyarakat

${ }^{49}$ Hasil wawancara dengan Surach Winarni selaku pakar hukum perbankan sekaligus Kepala Divisi Operasional Bank Mandiri wilayah Yogyakarta-Jawa Tengah pada tanggal 6 Januari 2016.

${ }^{50}$ Pasal 1 angka 4 POJK Nomor 19/POJK.03/2014 tentang Layanan Keuangan Tanpa Kantor Dalam Rangka Keuangan Inklusif 
pengguna layanan. ${ }^{51}$ Melalui fungsi yang demikian, agen diharapkan dapat menjadi pihak yang mampu meningkatkan jumlah transaksi perbankan di dalam masyarakat. ${ }^{52}$

Peraturan OJK tentang Laku Pandai sebagai landasan hukum bagi eksistensi agen Branchless Banking di Indonesia dapat dikatakan belum memberikan definisi hukum yang memadai terhadap kedudukan agen. Pada tataran selanjutnya hal ini berimplikasi pada munculnya persoalan mengenai sejauhmana pembebanan tanggung kepada agen dalam penyelenggaraan Branchless Banking. ${ }^{53}$

Peraturan OJK mengenai Laku Pandai mendefiniskan agen sebagai pihak yang bekerjasama dengan Bank penyelenggara Laku Pandai yang menjadi kepanjangan tangan Bank untuk menyediakan layanan perbankan kepada masyarakat dalam rangka keuangan inklusif sesuai yang diperjanjikan. ${ }^{54}$ Berdasarkan rumusan definisi Agen dimaksud, sejatinya dapat dipahami bahwa hak dan kewajiban Agen Branchless Banking berasal dari peraturan perundangundangan dan perjanjian.

Peraturan perundang-undangan dalam hal ini merujuk pada setiap peraturan perundang-undangan yang mendasari kegiatan perbankan mulai dari UndangUndang Perbankan ${ }^{55}$ hingga peraturan pelaksanannya. Sementara perjanjian yang mendasari munculnya hak dan kewajiban agen dalam pelaksanaan operasional Branchless Banking bersumber dari perjanjian ${ }^{56}$ antara setiap agen dengan bank penyelenggara masing-masing.

51 Masyarakat pengguna layanan Branchless Banking ini meliputi baik masyarakat yang telah menjadi nasabah bank maupun masyarakat yang bekum menjadi nasabah bank.

52 Perwujudan keuangan inklusi ini sebagaimana telah dicanangkan oleh Bank Indonesia dengan menetapkan enam pilar Strategi Nasional Keuangan Inklusi (SNKI) yakni: edukasi keuangan, fasilitas keuangan publik, pemetaan informasi keuangan, kebijakan/peraturan yang mendukung, fasilitas intermediasi dan saluran distribusi serta perlindungan konsumen. Lihat: Enam Pilar Strategi Nasional Kenangan Inklusif, www.bi.go.id diakses pada tanggal 19 Januari 2017.

53 Pasal 22 Angka 2 POJK Nomor 19/POJK.03/2014 tentang Layanan Keuangan Tanpa Kantor Dalam Rangka Keuangan Inklusif.

54 Pasal 1 angka 4 POJK No. 19/POJK.03/2014 tentang Layanan Keuangan Tanpa Kantor Dalam Rangka Keuangan Inklusif.

55 Undang-Undang Nomor 7 Tahun 1992 tentang Perbankan jo. Undang-Undang Nomor 10 Tahun 1998 tentang Perubahan atas Undang-Undang Nomor 7 Tahun 1992 beserta peraturan pelaksaan terkait seperti POJk Nomor 19/POJK.03/2014 tentang Layanan Keuangan Tanpa Kantor Dalam Rangka Keuangan Inklusif.

56 Perjanjian antara Agen dengan Bank Penyelenggara Branchless Banking ini termasuk ke dalam kategori perjanjian standar. Di dalam praktek, masing-masing bank penyelenggara diberikan hak untuk menentukan sendiri isi perjanjian sepanjang tidak bertentangan dengan pengaturan umum sebagaimana terdapat di dalam POJK No. 19/POJK.03/2014 tentang Layanan Keuangan Tanpa Kantor Dalam Rangka Keuangan Inklusif. Hasil wawancara 
Hak dan kewajiban para pihak baik yang bersumber dari peraturan perundang-undangan maupun yang bersumber dari perjanjian menimbulkan adanya konsekuensi hukum ${ }^{57}$ berupa hak dan kewajiban. Pada tataran selanjutnya, pelaksanaan kewajiban agen memiliki konsekuensi hukum yang termanifestasi ke dalam bentuk tanggung jawab hukum. ${ }^{58}$

Belum jelasnya pengaturan mengenai kedudukan hukum agen Laku Pandai dapat menimbulkan kesulitan dalam menentukan bentuk tanggung jawab yang tepat bagi agen Laku Pandai sebagai konsekuensi dari pelaksanaan kewajibannya sebagai agen. Hal ini menimbulkan sebuah pertanyaan mendasar sebagaimana telah disinggung, yakni 'apakah konstruksi keagenan yang mendudukkan posisi agen sebagai perantara sebagaimana terdapat dalam konsepsi keperantaraan dunia bisnis sama dengan konstruksi keagenan sebagaimana terdapat dalam Laku Pandai?'. Berdasarkan pada pertanyaan demikian, peneliti melakukan pengkajian terhadap kedudukan hukum agen Laku Pandai melalui perbandingan dengan bentuk kedudukan hukum agen yang berlaku dalam teori keagenan sebagai bagian dari keperantaraan dunia bisnis.

Hukum perdata Indonesia mengenal istilah agen sebagai pihak yang memiliki hubungan hukum dengan prinsipal berdasarkan suatu kontrak keagenan. Prinsipal merupakan pihak yang memberikan kewenangan kepada pihak lain (perantara) untuk melakukan perbuatan hukum tertentu. ${ }^{59}$ Apabila konstruksi keagenan yang demikian disandingkan dengan konstruksi kedudukan hukum para pihak dalam mekanisme Branchless Banking, maka bank penyelenggara Branchless Banking berkedudukan sebagai prinsipal. Sesuai dengan kedudukannya selaku prinsipal, bank memberikan kewenangan kepada agen untuk melakukan perbuatan hukum guna kepentingan prinsipal.60

dengan Inu Surach Winarni selaku pakar hukum perbankan sekaligus Kepala Divisi Operasional Bank Mandiri Wilayah Yogyakarta-Jawa Tengah pada tanggal 6 Januari 2016.

57 Berdasarkan Pasal 1233 KUH Perdata, perikatan dapat lahir dari perjanjian atau undang-undang (verbintenissen onstaan nit overeenkomst, of uit de wet). Lihat: Ridwan Khairandy, Hukum Kontrak Indonesia Dalam Perspektif Perbandingan (Bagian Pertama), FH UII Press, Yogyakarta, 2013, hlm.17.

58 Khusus terhadap kewajiban yang lahir berdasarkan perjanjian, KUH Perdata menentukan bahwa tanggung jawab hukum (yang salah satunya berupa pembayaran ganti rugi) akan muncul apabila pihak debitor tidak melaksanakan prestasi karena suatu kesalahan. Lihat: Ridwan Khairandy, Hukum Kontrak Indonesia ..., Op. Cit., hlm. 278.

${ }^{59}$ Kamus Bisnis dan Perbankan, http://www.mediabpr.com/kamus-bisnis-bank/prinsipal.aspx diakses pada tanggal 19 Februari 2016

${ }^{60}$ Ridwan Khairandy, Hukum Kontrak Indonesia..., Loc. Cit. 
Masih berdasarkan pada konstruksi hukum yang sama, maka seorang agen memiliki kedudukan hukum sebagai perantara. Berdasarkan kedudukan hukumnya sebagai perantara maka agen tidak memiliki tanggung jawab hukum kepada pihak ke tiga yang menderita kerugian sebagai akibat pelaksanaan tugasnya sepanjang pelaksanaan tugas telah sesuai dengan kewenangan yang diberikan oleh prinsipal.

Konsekuensi hukum yang timbul bagi agen Branchless Banking di Indonesia, apabila merujuk kepada konsepsi keagenan sebagaimana dimaksud adalah lepasnya tanggung jawab agen terhadap berbagai hubungan hukum yang terjadi dengan pihak ke tiga. Tanggung jawab hukum yang timbul dari pelaksanaan kewajiban agen selaku perantara tetap berada pada Bank selaku prinsipal. Hal ini dapat dipahami karena agen sejatinya bukanlah pihak di dalam perjanjian yang terjadi antara prinsipal dengan pihak ke tiga.

Konstruksi kedudukan hukum beserta tanggung jawab yang demikian dirasa kurang tepat untuk diterapkan terhadap agen Branchless Banking. Pendapat ini didasarkan pada argumentasi bahwa pada kenyataannya terdapat perbedaan mendasar antara kedudukan dan fungsi agen dalam konsepsi keperantaraan bisnis dengan kedudukan dan fungsi agen Branchless Banking.

Agen dalam keperantaraan bisnis umumnya hanya berkedudukan sebagai perantara di dalam transaksi bisnis tertentu (missal, jual beli) guna kepentingan prinsipal. Agen dalam keperantaraan bisnis secara riil tidak menjadi pihak di dalam suatu perikatan yang terjadi antara prinsipal dengan pihak ke tiga. ${ }^{61}$ Sebagai konsekuensi yuridis atas kedudukan agen sebagai perantara, maka agen tidak memiliki tanggung jawab hukum terhadap perikatan yang terjadi antara prinsipal dengan pihak ke tiga mengingat perikatan hanya mengikat prinsipal dengan pihak ke tiga. ${ }^{62}$

${ }^{61}$ Ibid.

${ }^{62}$ Sebagai perbandingan, baca: Aster Kusumastuti, "Tanggung Jawab Agen Kepada Nasabah Penyimpan dan Simpanannya Terhadap Layanan Perbankan Branchless Banking (Ditinjau Dari Peraturan Otoritas Jasa Keuangan Nomor 19/POJK.03/2014 tentang Layanan Keuangan Tanpa Kantor Dalam Rangka Keuangan Inklusif”, 2015, Jurnal Ilmiah, Fakultas Hukum Universitas Brawijaya. http://www.portalgaruda.org Khusus mengenai tanggung jawab agen terhadap rahasia bank baca: Ajeng Noorseta Quadtias Kumitriasih, "Tanggung Jawab Agen Layanan Keuangan Tanpa Kantor Dalam Rangka Keuangan Inklusif Terhadap Rahasia Bank”, 2015, Jurnal Ilmiah, Fakultas Hukum Universitas Brawijaya. http://www.portalgaruda.org. 
Pada sisi lain, kedudukan agen Branchless Banking memiliki perbedaan mendasar apabila dibandingkan dengan kedudukan agen dalam konsep keperantaraan dunia bisnis. Perbedaan diantara keduanya terutama dapat dikaji berdasarkan lingkup kegiatan yang dapat dilakukan oleh agen Branchless Banking. Agen Branchless Banking dapat melakukan berbagai kegiatan di bidang perbankan, seperti membuka rekening, menerima simpanan serta menyalurkan pinjaman. ${ }^{63}$ Hal ini berbeda dengan agen dalam keperantaraan bisnis yang pada umumnya hanya dapat melakukan suatu perbuatan hukum tertentu.

Peneliti telah pula melakukan wawancara dengan agen Branchless Banking pada dua bank di Indonesia. Agen tersebut menuturkan bahwa di dalam proses penunjukannya sebagai agen, agen bersangkutan tidak mengetahui secara terperinci mengenai bentuk dan isi kontrak antara agen dengan bank yang diwakilinya. Selain itu, beberapa aspek penting berkaitan dengan pelaksanaan tugas agen disampaikan secara lisan oleh pihak bank. Salah satunya yakni penjelasan agar agen bersifat hati-hati dalam menjalankan fungsinya sebagai agen. ${ }^{64}$

Hal tersebut mengarah kepada adanya pembebanan tanggung jawab kepada agen untuk melaksanakan prinsip kehati-hatian perbankan secara implisit. Mengenai hal ini peneliti berpendapat bahwa pemberian penjelasan secara lisan terhadap kewajiban pelaksanaan prinsip kehati-hatian ini sekiranya tidak tepat mengingat prinsip kehati-hatian merupakan prinsip utama dalam kegiatan perbankan tak terkecuali Branchless Banking.

Bedasarkan uraian baik terhadap segi normatif maupun praktik penyelenggaraan Branchless Banking sebagaimana telah diuraikan, maka dapat ditarik sebuah kessimpulan bahwa tanggung jawab Agen Branchless Banking memiliki cakupan yang lebih luas dan tidak dapat dipersamakan dengan tanggung jawab agen sebagaimana dikenal dalam perjanjian keagenan. Seorang Agen Branchless Banking secara mendasar bertanggung jawab untuk melaksanakan

${ }^{63}$ Baca Buku Saku Laku Pandai, 2014, Otoritas Jasa Keuangan Republik Indonesia.

${ }^{64}$ Hasil Wawancara dengan Ibu Lismawati selaku Agen Branchless Banking pada salah satu bank pemerintah di Indonesia pada tanggal 15 Januari 2016. 
segala ketentuan hukum sebagaimana dibebankan pada penyelenggaraan kegiatan perbankan.

\section{Penutup}

Bentuk hubungan hukum yang terjadi antara bank dengan agen dalam penyelenggaraan Branchless Banking berbeda dengan bentuk hubungan hukum yang terjadi antara agen dengan prinsipal berdasarkan perjanjian keagenan. Regulasi Laku Pandai yang masih belum memberikan pengaturan secara jelas dan lengkap mengenai hubungan hukum para pihak berpotensi menyebabkan munculnya persoalan hukum khususnya berkaitan dengan tanggung jawab agen Laku Pandai.

Tanggung jawab hukum yang dibebankan kepada agen dalam penyelenggaraan Branchless Banking (Laku Pandai) di Indonesia tidak dapat dipersamakan dengan tanggung jawab hukum yang dibebankan kepada Agen sebagaimana muncul dari suatu perjanjian keagenan. Tanggung jawab Agen dalam penyelenggaraan Branchless Banking bersumber dari peraturan perundangundangan dan perjanjian antara setiap agen dengan masing-masing bank penyelenggara. Agen Branchless Banking secara mendasar bertanggung jawab untuk melaksanakan segala kewajiban berdasarkan ketentuan hukum yang berlaku bagi penyelenggaraan kegiatan perbankan pada umumnya.

\section{Daftar Pustaka}

\section{Buku}

Burton, Richard, Aspek Hukum dalam Bisnis, Rineka Cipta, Jakarta, 2003.

Carnell, Macey, Miller, the Law of Banking and Financial Institution: Fourth Edition, New York, Aspen Publisher, 2009.

Ibrahim, Johny, Teori dan Metodologi Penelitian Normatif, Banyumedia Publishing, Malang, 2006.

Khairandy, Ridwan, Pokok-Pokok Hukum Dagang Indonesia, FH UII Press, Yogyakarta, 2013.

, Hukum Kontrak Indonesia Dalam Perspektif Perbandingan (Bagian Pertama), FH UII Press, Yogyakarta, 2013.

Mertokusumo, Sudikno, Mengenal Hukum Suatu Pengantar, Penerbit Liberty, Yogyakarta, 2005. 
Otoritas Jasa Keuangan Republik Indonesia, Buku Saku Laku Pandai, 2014.

Satrio, J., Hukum Perjanjian, Bandung, PT. Citra Aditya Bakti, 1992.

Usman, Rachmadi, Aspek Aspek Hukum Perbankan di Indonesia, PT Gramedia Pustaka Utama, Jakarta, 2003.

\section{Jurnal}

Kumitriasih, Ajeng Noorseta Quadtias, “Tanggung Jawab Agen Layanan Keuangan Tanpa Kantor Dalam Rangka Keuangan Inklusif Terhadap Rahasia Bank", 2015, Jurnal Ilmiah, Fakultas Hukum Universitas Brawijaya. http:/ / www.portalgaruda.org.

Kusumastuti, Aster, “Tanggung Jawab Agen Kepada Nasabah Penyimpan dan Simpanannya Terhadap Layanan Perbankan Branchless Banking (Ditinjau Dari Peraturan Otoritas Jasa Keuangan Nomor 19/POJK.03/2014 tentang Layanan Keuangan Tanpa Kantor Dalam Rangka Keuangan Inklusif", 2015, Jurnal Ilmiah, Fakultas Hukum Universitas Brawijaya. http:/ / www.portalgaruda.org

Subramanian, Shri L.S., "a Study of Branchless Banking in Achieving Financial Inclusion in India". BVIMSR's Journal of Management Research. Vol. 5 Issue 2: October 2013.

\section{Hasil Penelitian}

Rahmaningrum, Alifa Prasasti, Tinjauan Yuridis Atas Risiko Penyelenggaraan Branchless Banking Dalam Kaitannya Dengan Kesehatan Bank, Tesis, Magister Ilmu Hukum Fakultas Hukum Universitas Gadjah Mada, 2013.

\section{Peraturan Perundang-Undangan}

Kitab Undang-Undang Hukum Dagang

Kitab Undang-Undang Hukum Perdata

Undang-Undang Republik Indonesia Nomor 10 Tahun 1998 tentang Perubahan atas Undang-Undang Nomor 7 Tahun 1992 tentang Perbankan (Lembaran Negara Republik Indonesia Tahun 1998 Nomor 182, Tambahan Lembaran Negara Republik Indonesia Nomor 3790).

Undang-Undang Republik Indonesia Nomor 21 Tahun 2011 tentang Otoritas Jasa Keuangan (Lembaran Negara Republik Indonesia Tahun 2011 Nomor 111, Tambahan Lembaran Negara Republik Indonesia Nomor 5253).

Undang-Undang Republik Indonesia Nomor 7 Tahun 1992 tentang Perbankan (Lembaran Negara Republik Indonesia Tahun 1992 Nomor 31, Tambahan Lembaran Negara Republik Indonesia Nomor 3790).

Peraturan Bank Indonesia Nomor 11/12/PBI/2009 tentang Uang Elektronik

Peraturan Otoritas Jasa Keuangan Nomor 19 .03/POJK Tahun 2014 tentang Layanan Keuangan Tanpa Kantor Dalam Rangka Keuangan Inklusif 
Peraturan Bank Indonesia Nomor 18/17/PBI/2016 tentang Perubahan Kedua atas PBI Nomor 11/12/PBI/2009 tentang Uang Elektronik

\section{Internet}

Anonim, "Pengertian Pendapatan Nasional", http://www.bps.go.id

Anonim, "Solusi Kemudahan Transaksi Branchless Banking", http://www.bca.co.id

Claire Alexandre, "What Can Branchless Banking Do to Advance the Field, and What Can It Not Do? From Mobile Banking to Point of Service" artikel pada 2011 Global Microcredit Summit, 2011.

Kamus Bisnis dan Perbankan, http://www.mediabpr.com

Paula J. Dalley, "A Theory of Agency Law", https://lawreview.law.pitt.edu

Siaran Pers Otoritas Jasa Keuangan, "OJK Resmikan Program Laku Pandai", http://www.ojk.go.id

Soerjono Soekanto, Pengantar Penelitian Hukum, Penerbit Universitas Indonesia, Jakarta, 2006.

Enam Pilar Strategi Nasional Keuangan Inklusif, www.bi.go.id

The Consultative Group to Assist for the Poor, Branchless Banking Agents in Brazil: Building Viable Networks. February, 2010.

Timothy R. Lyman, Gautam Ivatury, and Stefan Staschen, "Use of Agents in Branchless Banking for the Poor: Rewards, Risk and Regulation", The Consultative Group to Assist the Poor, Focus Note Number 38, October 2008, http://www.cgap.org

World Bank, "Financial Access", the Consultative Group to Assist the Poor, 2009, http://www.worldbank.org 